\title{
Az ÁRNYÉKOKTATÁS OKTATÁSGAZDASÁGI KÖZELÍTÉSBEN
}

\author{
POLÓNYI ISTVÁN
}

Debreceni Egyetem Bölcsészettudományi Kar, Nevelés- és Müvelődéstudományi Intézet

A tanulmány először az árnyékgazdaságot, valamint annak egyik sajátos magyar változatát a második gazdaságot definiálja, majd az árnyékoktatást ehhez viszonyítva igyekszik meghatározni, s a két jelenség közötti összefüggést vizsgálni.

Ezt követően az árnyékoktatás formáit tekinti át az írás. Majd a különböző gazdasági elméletek és megközelítések aspektusából veszi górcső alá az árnyékoktatást.

A tanulmány befejezésül megállapítja, hogy az árnyékoktatás lényegében a piac reagálása a hivatalos oktatási rendszer olyan sajátosságaira, mint az egyéni igények és képességek különbségeinek kezelésére való képtelenség vagy azoknak szándékos egalitárius kezelése, továbbá annak alacsony színvonala. Az árnyékoktatás individualizációs hatása egyben a különböző társadalmi hátterű tanulók - akik gazdasági lehetőségei okán eltérő mennyiségü árnyékoktatás igénybevételére képesek és hajlandók - eltérő képességszintjének, tanulmányi teljesítményének forrása. Ezzel a társadalmi különbségek átszármaztatásának egyik eszköze, amit az állam, az oktatáspolitika sohasem tud megakadályozni, legfeljebb tompítani.

Kulcsszavak: árnyékoktatás, árnyékgazdaság, társadalmi egyenlőtlenségek

The study first defines the shadow economy and (in its peculiar Hungarian version) the second economy. The writing then defines and examines shadow education relative to the shadow economy.

Subsequently, the writing reviews the forms of shadow teaching. It then focuses on shadow education from the perspective of various economic theories and approaches.

The study concludes that shadow education is essentially a market response to the characteristics of the formal education system: that public education is unable to address individual needs and abilities, or that it deliberately egalitarianly treats everyone, or that public education is of low quality. At the same time, the individualisation effect of shadow education is also a source of different levels of ability and academic achievement of students from different social backgrounds (who are able and willing to use different amounts of shadow education due to their economic opportunities). Thus, shadow education is one of the means of transplanting social differences, which the state, education policy, can never prevent, but only mitigate.

Keywords: shadow education, shadow economy, social inequalities

Levelező szerző: Polónyi István, Debreceni Egyetem Bölcsészettudományi Kar, Nevelés- és Művelődéstudományi Intézet, 4032 Debrecen, Egyetem tér 1. E-mail: istvan.polonyi@arts.unideb.hu 


\section{Bevezetés}

$\mathrm{E}$ $z$ az írás (oktatás)gazdasági szemüvegen keresztül vizsgálja az árnyékképzést vagy árnyékoktatást (shadow education), amelyet ezeken kívül a vonatkozó irodalom elég sok néven illet, pl. private tutoring vagy private supplementary tutoring, ami lényegében mindegyik magánoktatást jelent, amely az iskolarendszeren kívül folyik. (A magánoktatás szó magyarul inkább az alternatív iskolákat jelenti, de itt az iskolarendszeren kívüli magánképzések jelentéssel fogjuk használni, esetenként a privát tutorálás, privát oktatás szóval felváltva.)

Először az árnyékgazdaság és az árnyékoktatás viszonyát vizsgáljuk meg, majd az árnyékoktatás fajtáit tekintjük át, végül pedig a jelenség humán tőkére gyakorolt hatásával és a jelenséget elemző közgazdasági elméletekkel foglalkozunk.

\section{$\mathrm{A} z$ árnyékgazdaság és árnyoktatás}

$\mathrm{A} z$ árnyékgazdaságot, amelyet néha informális, rejtett, fekete, párhuzamos, másodlagos vagy földalatti gazdaságnak (vagy szektornak) is neveznek, Hart (2008) úgy határozza meg, mint olyan gazdasági tevékenységet, amely a bürokratikus állami és magánszektorbeli intézmények keretein kívül zajlik. Ibrig és Moe (2004) tanulmánya olyan szektorként határozza meg, amely legális javakat állit elö, de nem felel meg a kormány rendeleteinek (idézi Elgin-Oztunali 2012).

$\mathrm{A} z$ árnyékgazdaságot a közgazdasági irodalom alapvetően az adómegkerülés aspektusából definiálja. A nem megfigyelt gazdaságnak (Non-Observed Economy) vagy árnyékgazdaságnak olyan kategóriáit különböztetik meg, mint a „szándékosan nem regisztráló termelők” (producers deliberately not registering), „szándékosan téves jelentést benyújtó termelők" (producers deliberately misreporting), „fel nem mért jogi személyek” (legal persons not surveyed) stb. (lásd Adair 2012).

Az IMF közelmúltban kiadott anyaga (Medina-Schneider 2018) úgy definiálja az árnyékgazdaságot, hogy az "magában foglal minden olyan tevékenységet, amelyet monetáris, szabályozási és intézményi okokból elrejtenek a bivatalos hatóságoktól. A monetáris okok között szerepel az adók és minden társadalombiztosítási járulék fizetésének elkerülése, a szabályozási okok között szerepel a kormányzati bürokrácia vagy a szabályozási keret terheinek elkerülése, míg az intézményes okok között szerepel a korrupciós törvény, a politikai intézmények minősége és a gyenge jogállamiság."

$\mathrm{A} z$ árnyékgazdaság terjedelmének mérése meglehetősen nehéz - hiszen az árnyékban müködő tevékenységről van szó -, ennek ellenére számos módszerrel próbálják azt meghatározni. Az IMF 2018-as kiadványa alapján (Medina-Schneider 2018) az 50 legfejlettebb ország ${ }^{1}$ között 2015-ben Brazília és Oroszország állt az élen a GDP harmadát kitevő árnyékgazdasággal, és Hollandia, Németország, az USA és Svájc állt a végén 8\%-nál kisebb aránnyal. Magyarország 20,5\%-kal a 17. volt Bulgária és Szlovénia között.

A kiadvány 150 országra adja meg az árnyékgazdaság terjedelmét a GDP-hez viszonyítva, - itt most az 50 legfejlettebb ország adatairól van szó, ami az OECD-, az EU- és a G20-országokat jelenti együttesen. 
Ha hosszabb idő távlatában nézzük, akkor Magyarországon az árnyékgazdaság a 80-as években $27-32 \%$ körül $^{2}$ volt, ami az ezredfordulóra $25 \%$ körülire mérséklödött, s a 2010 -es évek közepén $20 \%$ lett.

A hazai szakirodalomban a második gazdaság kutatása nyert jelentős teret a rendszerváltást megelőzően. A második gazdaság „definíciója szerint [...] magában foglal minden olyan termelő és elosztó tevékenységet, amely eleget tesz a következő két kritériuma egyikének: a) magánhaszon szerzésére irányul, b) sérti a fennálló jogrendet." (Grossman [1977/1982]: 245, idézi Sik 1996 - kiemelés PI.) Grossman egyik követője Bruno Dallago inkább a nem hivatalos gazdaság meghatározására a földalatti gazdaság fogalmat használja, ami a javak és szolgáltatások szervezetlen (nem bivatalos) kínálatát jelenti (Sik 1996).

„Amikor a hetvenes évek végén Magyarországon gondolkodni kezdtek a később második gazdaságnak elkeresztelt jelenségről, akkor [...] szinte magától értetődő volt a második gazdaság kifejezés választása” - írja Sik (1996), majd hozzáteszi, hogy „igaz, legszívesebben a magángazdasági szféra fogalmat használták volna”. „Mindazonáltal a második gazdaság fogalma nem puszta átvétele a grossmani definíciónak. Részben egyszerűbb annál (minden munka, ami nem a szocialista szektorban folyik és minden jövedelem, ami nem itt kerül elosztásra, a széles értelemben vett második gazdaságba tartozik), részben bonyolultabb nála (háromdimenziós tipológia épül a fogalomba sorolt sokszínű jelenség-együttes elrendezésére)." (Sik 1996: 708.)

A második gazdaság tehát olyan árnyékgazdaság, ami az államszocialista rendszer ideológiája nyomán szorul árnyékba.

Egyes kutatók szerint az árnyékgazdaság megjelenése torzítja a humántőke növekedését ösztönző eszközök alkalmazását (Ciutiene et al. 2015). Az árnyékgazdaság ugyanis csökkenti az állami termelékenység átlagos szintjét, ezáltal pedig egy ország növekedését. Az általános elgondolással ellentétben az empirikus tanulmányok kimutatták, hogy amikor a hivatalos gazdasági tevékenység mennyisége növekszik, az árnyékgazdaság is növekszik. Ezért az árnyékgazdaság társadalmi romlást is okozhat (Ciutiene et al. 2015).

$\mathrm{A} z$ árnyékoktatás széles körben ismert kutatója, Mark Bray magánkézben lévő kiegészítő oktatásként határozza meg az árnyékoktatást. Mint írja, az ilyen kiegészítő oktatást széles körben árnyékképzésnek nevezik. A metaforát azért használják, mert sok oktatás utánozza a mainstream iskolarendszert. Ha egy új tantervet vagy értékelési módot vezetnek be a mainstreamben, akkor az idővel az árnyékban is megjelenik. Ahogy a mainstream bővül, az árnyék is növekszik (Bray 2011).

Fontos hozzátenni, hogy az árnyékképzés elsősorban a magánkézben lévő oktatás, amely profitszerzésre irányul és nem nonprofit elven vagy jótékonyságból működik (Kim-Jung 2019). - (Később kitérünk az árnyékképzés formáira.)

A meghatározásból is adódik, hogy az árnyékoktatás nem a teljes hányada - sőt lehetséges, hogy csak kisebb hányada -, része az árnyékgazdaságnak gazdasági értelemben. Ugyanakkor, mint Bray írja, sok szereplő szándékosan kerüli az átláthatóságot Bray (2011), illetve több nemzetközi szerzőre hivatkozik, akik az árnyékoktatást a „szürke gazdaság” részének tekintik. (Uo.) Aurini és Davies úgy fogalmaz, hogy „a privát tutorálás a kiegészítő oktatás egy formája, amely nem versenyez közvetlenül az állami iskolákkal. Az oktatók inkább egy réspiacot faragtak a közrend szélén, extrasegítséget

Az IMF-tanulmány szerint 1991-ben 31,9\% volt (Medina-Schneider 2018), egy másik tanulmány szerint 1981-ben 25,3\%, 1991-ben 27,0\% (Ceybun-Öztunali 2012). 
POLÓNYI ISTVÁN: AZ ÁRNYÉKOKTATÁS OKTATÁSGAZDASÁGI KÖZELÍTÉSBEN




nyújtva a diákoknak, amelyet a rendes iskolákban nehéz megszerezni." (Aurini-Davies 2004: 422.) Tehát az árnyékoktatás szakmai, oktatáspolitikai és társadalompolitikai értelemben határos az árnyékgazdasággal.

$\mathrm{Az}$ 1. táblázat alapján jól látszik, hogy az árnyékoktatásban való részvétel és az árnyékgazdaság között együttmozgás van - a 2012. évi adatokkal számolva -, a bemutatott OECD-országok halmazán közepes pozitív a korreláció (+0,4390).

A táblázat alapján az is egyértelmüen látszik - amit számos tanulmány megállapított, pl. Buchmann-Condron-Roscigno 2010; Byung-Chung-Baker 2018 stb. -, hogy a magasabb szocioökonómiai státusú családból származó gyermekek nagyobb valószínűséggel használják az árnyékképzést. Az is kiderül, hogy az országok nagy részében az alacsony iskolai teljesítményű gyermekek is nagyobb valószínűséggel használnak árnyékképzést. Ugyanakkor ez utóbbi tendenciától a távol-keleti országok (Japán, Korea) eltérnek.

\section{Az árnyékoktatás fajtái}

A privát képzésnek több formája létezik. Bray a formákat így foglalja össze: „A privát oktatás formái változatosak lehetnek. Néhány oktatást személyesen biztosítanak az oktató vagy az ügyfele otthonában. Másik forma kis csoportokban, nagy osztályokban vagy akár hatalmas videoképernyővel ellátott előadó-színházakban történik. Néhány oktatást teljes egészében levelezéssel oldanak meg; és néhány társadalomban az oktatást telefonon biztosítják. Az a tény, hogy a magántulajdonban levő oktatást oly sok formában lehet biztosítani, az egyik oka annak, hogy nehéz vizsgálni” (Bray 1999: 22).

Kim és Jung igen részletesen elemzi az árnyékoktatás formát, öt fajtáját megkülönböztetve annak:

- Otthoni privát oktatás (Home-visit private tutoring = HVPT)

- Magántulajdonban lévő tutori intézmények (Private tutoring institutes = PTI)

- Előfizetett tanulási programok (Subscribed learning programs = SLP)

- Internet alapú privát oktatás (Internet-based private tutoring $=$ IPT)

- Iskola utáni programok (After-school programs = ASP) (Kim-Jung 2019)

1. Az otthoni privát oktatásában (Home-visit private tutoring $=$ HVPT) az oktató személyesen testre szabott oktatást nyújt egy diáknak, általában a hallgató otthonában. Ez az árnyékképzés leggyakoribb formája. Az oktatók általában együtt dolgoznak egy hallgatóval, de néha egynél több hallgató is van. Általában önálló vállalkozók, nincs szisztematikus irányítási rendszer vagy hivatalos kapcsolattartás más oktatókkal. A HVPT az árnyékképzés egyik leggyakoribb formája, és Észak-Amerikában, Európában, továbbá néhány ázsiai országban megtalálható, beleértve Indiát, Hongkongot, Dél-Koreát és Japánt. A HVPT dijai magasabbak, mint az árnyékképzés bármely más formája esetében, így a viszonylag gazdag családokból származó hallgatók számára hozzáférhető ez a képzés. (Kim-Jung 2019: 61-62.) A szerzők azt is leszögezik, hogy ezeknek a magas díjaknak köszönhetően a HVPT reprodukálhatja az oktatási egyenlötlenségeket. (Uo.) A szerzők megkülönböztetnek háromféle HVPT képzést:

a) Az egy az egyben oktatás esetében a tutor-tanuló arány $1: 1$, és az oktatás jellemzője az egyéni igények szerinti képzés. Ez a legdrágább forma.

b) A csoportos tutorálásnál az oktató-tanuló arány 1:2-5. Ez olcsóbb, mint az egyegyben oktatás. Itt általában képesség szerinti csoportokat alakítanak ki. 
c) A vállalati típusú otthoni privát oktatásnál lehet $1: 1$ vagy $1: 2-5$ oktató-tanuló arány. A képzést a vállalatok által nyújtott oktatási útmutatók segítik és félig strukturált tanítási/tanulási anyagokat biztosítanak. Általában internetes formában szerveződik (Kim-Jung 2019: 63).

A HVPT jellemzői a személyre szabott tanulás, a rugalmas tantervek és oktatási módszerek, az oktatók és a tanárok közötti intim kapcsolat.

2. A magántulajdonban lévő tutori intézmények (Private tutoring institutes $=$ PTI) az árnyéknevelés leginkább iskolai jellegű formái, mivel infrastruktúrával, osztálytermekkel rendelkeznek. A PTI hasonló a balett, a zene és a művészeti magániskolákhoz, azzal a különbséggel, hogy az iskolai tárgyakra és a teszt előkészítésére összpontosítanak. Rendelkeznek formális programokkal és hivatalos menetrendekkel, tananyagokkal, osztályokkal és értékelési módszerekkel. A PTI-hallgatók általában hetente háromszor járnak a képzésre. Az osztályok mérete 7-15 fó, esetleg nagyobb lehet. Általában képességek alapján csoportosítják a hallgatókat osztályokba. Sok PTI a közelmúltban franchiserendszerbe szerveződött. A PTI-knek különféle nevei vannak a különböző országokban. A kelet-ázsiai országokban a legmagasabb az ilyen intézményekben a részvételi arány. A PTI sok országban nagy iparággá vált. Japánban a jukuipar évente 12 milliárd dollárt generál. Dél-Koreában a magán oktatási piac mérete a 2000. évi 6,5 milliárd dollárról 2003-ra 16,5 milliárd dollárra bővült. A bővítés nyomán 221 franchise-alapú koreai PTI-vállalat exportálta tanulási tartalmát külföldre. (Kim-Jung 2019: 65.) A szerzők a PTI-ket négy csoportba sorolják:

a) Az egytárgyú PTI-k, amelyek egy adott tárgyat oktatnak (matematika, angol vagy más nyelv, természettudomány, társadalomtudomány). Jellemzőjük a szakértelem az adott tárgyban. Céljuk a felzárkóztatás vagy a fejlesztés.

b) Komprehenzív PTI-k, ahol különböző tantárgyak szisztematikus tanulása folyik elfogadható áron. Céljuk a felzárkóztatás, fejlesztés, iskolai tesztekre felkészítés, alapvető tanulási készségek kialakítása, rendszeres tanácsadás.

c) Tehetséges hallgatókat képző PTI-k. Jellemzőjük, a mélyreható tartalom az iskolai tantárgyakban. Céljuk elitoktatás nyújtása kiemelkedően haladó tanulók számára, az iskolai végzettség növelésének elősegítése, felkészülés a magasabb szintű iskolai felvételre.

d) Tesztírásra felkészítő PTI-k. Jellemzőjük a jelentős tesztekre, középiskolai vagy felsőoktatási felvételi vizsgatesztekre (SAT ${ }^{3}, \mathrm{TOEFL}^{4}, \mathrm{GRE}^{5}, \mathrm{GMAT}^{6}$, esszéteszt stb.) való felkészítés, felvételi konzultáció (stratégiai tanácsadás és információk). (Kim-Jung 2019: 67.)

SAT teszt: az Egyesült Államokban a 20. század elején bevezetett, a felsőoktatási felvételi eljárásokban alkalmazott teszt. (A SAT rövidítés: Scholastic Aptitude Test, illetve Scholastic Assessment Test.) (Magyar 2009.)

4 TOEFL: angol nyelvi teszt (Test of English as a Foreign Language). Számos angol nyelvủ felsőoktatási intézmény ezt a nyelvvizsgát jelöli meg felvételi követelményként a nem angol anyanyelvű jelentkezők számára (https://angolvizsga.hu/content/TOEFL.php).

5 GRE teszt: Graduate Record Examinations, egy standardizált felvételi teszt, amelyet a PhD-képzésre történő felvételnél használnak az angolszász országokban.

6 GMAT teszt: Graduate Management Admission Test általában posztgraduális üzleti képzésre (pl. MBA) való felvételnél használt standardizált teszt, főleg az angolszász országokban. 
A PTI-k legfontosabb jellemzői: 1) az általános tanterv és oktatás, 2) differenciált osztályok, 3) folyamatos értékelés és 4) tanácsadási szolgáltatás. Az iskolákkal ellentétben, amelyek félévenként vagy évente csak egyszer vagy kétszer végeznek formális teszteket, a PTI-k gyakori értékeléseket alkalmaznak a tanulók megértésének és előrehaladásuknak a felmérésére. A PTI-k általában diagnosztikai eszközöket fejlesztenek ki, hogy meghatározzák az egyes hallgatók tanulmányi előrehaladását, akadémiai erősségeit és gyengeségeit, valamint az iskola és a tanulás általános ismereteit. (Kim-Jung 2019: 69-70.)

3. Az előfizetett tanulási program (SLP) szabványosított és szisztematikus oktatóprogram, amelyet nagy franchise vállalkozások biztosítanak. ${ }^{7}$ A hallgatók előfizetnek ezekre a tananyagokra, mint egy magazinra. Az SLP-társaságok saját tanterveik és oktatási stratégiáik alapján fejlesztik ki anyagaikat, különösen a munkalapokat és a tanulási tartalmakat, amelyek csak előfizetéses formában érhetők el. Az anyagokat postán kézbesítik, és a tanulók lépésről lépésre követik őket otthon, saját tempójukban. A legtöbb vállalat hetente egyszer küld oktatókat is a hallgatók otthonaiba. A HVPT-vel ellentétben ezeknek az oktatóknak az a szerepük, hogy felmérjék a hallgató fejlődését és megértésének fokát, irányítsák őket a következő feladatokra, és segítsék őket a tantárgy és a tanulási stratégiákkal kapcsolatos egyéb kérdések kezelésében.

$\mathrm{A} z$ SLP-k kezdetben a nyomtatott munkalapokkal dolgoztak, ám az utóbbi időben kibővült a szolgáltatásuk. Most az SLP-k két fó módon nyújtanak szolgáltatást: otthoni látogatással vagy online/telefonos szolgáltatással kiegészítve.

$\mathrm{A} z$ SLP legfontosabb jellemzői 1) a kis lépések elvén alapuló strukturált tantervek és programok, 2) a tartalom elsajátítása ismétlődő gyakorlatok és visszajelzések segítségével, és 3) házi feladatok a jó tanulási szokások kialakítása céljából.

4. Az internetalapú privát oktatás (IPT) egyesíti a magánoktatás és a fejlett technológiák előnyeit. Az IPT az egyéni hallgatóknak online előadásokat, programokat, információkat, szolgáltatásokat és letölthető leckéket is kínálhat. Az internet azonnali online kommunikációt is lehetővé tesz a hallgatók és az oktatók között. Az IPT három fó típusát lehet megkülönböztetni:

a) Az archivált online előadásoknak online platformra történő feltöltése. Ezeket általában videofájlként rögzítik, és egy kijelölt webhelyen megtekinthetők. A hallgatók bármikor, bárhol elérhetik az internetes előadásokat a webhelyeken, számítógépükön, táblagépen, vagy okostelefonon keresztül. Az előadásokat - fizetés után - a hallgatók egy meghatározott időtartam alatt többször megnézhetik.

b) Az online oktatás. Ez lehetővé teszi a hallgatók és a tanárok közötti valós idejü interakciót. Az egyének vagy a tanulók csoportjai egyidejüleg bejelentkeznek a rendszerbe, és egy tanártól hallgathatnak előadásokat. Az ilyen típusú IPT rendszerint magában foglalja a tanuláskezelő rendszereket vagy a virtuális tanulási környezetet.

c) A vegyes tanulás az online és offline képzés kombinációja. A hallgatók számára előzetesen rögzített előadásokat kínálnak a webhelyeken, de segítséget kaphatnak, ha nem értik a tartalmat offline oktatásban.

Példaként a szerzők a Kumon, a Red Pen, a Prunet és a Noonnoppi cégeket említik (Kim-Jung 2019: 70). 
Az IPT három legfontosabb előnye: 1) a mindenütt jelen lévő tanulás lehetővé tétele, 2) az archivált online előadások egyedi kezelésének lehetővé tétele és 3) az önmenedzselés ösztönzése. (Kim-Jung 2019: 77-78.)

5. Az iskola utáni programok (After-school programs = ASP) úgy definiálhatók, mint olyan diákközpontú tanulási és fejlesztési tevékenységek halmaza, amelyek iskolai alapúak, de nem képezik a szokásos tanterv részét.

Az ASP-t az árnyékoktatás fogalmába lehet sorolni, mivel sok esetben a programokat magánoktatók vagy ügynökségek kínálják, akik szerződéssel rendelkeznek az iskolával. Dél-Koreában az ASP azért fejlődött ki, mert a kormány meg akart felelni a hallgatók különféle igényeinek. Célja: 1) a különféle társadalmi-gazdasági státuszú és régiókban élő diákok közötti oktatási szakadék csökkentése, 2) a családi struktúra társadalmi változásainak következtében növekvő gyermekgondozási és oktatási igények kezelése, 3) enyhíteni az oktatási költségeket azáltal, hogy felszívja a magánképzés iránti igényt a közoktatási szektorba, 4) segíteni a jól képzett egyének fejlődését és 5) javítani a PISA-felmérés nemzeti pontszámait.

A z ASP-k „egésznapos iskoláknak” vagy „iskola utáni tevékenységeknek” nevezhetők, gyakran nonprofit alapon szerveződnek. Számos országban léteznek az USA-tól, Svájcon és az Egyesült Királyságon át Japánig. (Kim-Jung 2019: 79.) Az ASP-k gyakorlatát a különféle országokban két fó típusba lehet sorolni:

a) A tantárgyalapú iskola utáni programok az iskolai tantárgyakat foglalják magukba: matematika, angol nyelv, társadalomtudomány, természettudomány stb. A hallgatók alacsony költséggel kiegészíthetik az iskolai tanulásukat. Ez a fajta program különféle szerepeket szolgál, beleértve házi feladatok elkészítésének segítését, felzárkóztatást, fejlesztést és tesztelőkészítést.

b) A készség- és tehetségfejlesztő ASP-k általában különböző programokat kínálnak sport, művészetek és előadóművészet, számítógépes ismeretek, vagy például életvezetési képességek területén. Ezek a programok segíthetnek a tanulók személyiségének, önbizalmának és társadalmi készségeinek javításában.

Az ASP legfontosabb jellemzői: 1) változatos célok és funkciók, 2) viszonylag alacsony költségek és 3) kormányzati szabályozás. (Kim-Jung 2019: 80-81.)

Kim és Jung azzal zárja áttekintését, hogy néhány ország, például Dél-Korea és Japán rendelkezik az árnyékképzés valamennyi formájával, ám nem minden országban található mindegyik meg. Arra lehet számítani, hogy az árnyékképzés további formái is meg fognak jelenni, különösen az árnyékképzés vegyes formái. (Kim-Jung 2019: 83.)

\section{A z árnyékoktatás gazdasági összefüggései}

Dang és Rogers - a standard közgazdasági megközelítés alapján - az árnyékoktatás mozgató rugóinak két szintjét különbözteti meg.

A mikrotényezők: a háztartások jövedelme, a szülők oktatással kapcsolatos preferenciája és a gyermekeik oktatási kiadásainak megtérülésével kapcsolatos elvárásai. Több nemzetközi kutatási eredményt áttekintve megállapítják, hogy azok a változók, amelyek a privát oktatás fogyasztását leginkább befolyásolják: a háztartások jövedelme, a szülők iskolázottsága és a városi lakóhely. 
A makrotényezők között - kelet-európai országok esetében - a piacgazdaságra való áttérést, az oktatás és a munka közötti kapcsolatok szorosságát, és ezzel kapcsolatban a képzés megtérülésének magas szintjét, a hiányos közoktatási rendszer rossz minőségének kompenzálását, továbbá az egyes országok kulturális értékrendjét emelték ki.

A szerzők hangsúlyozzák, hogy kevés az átfogó empirikus kutatás, ezért nehéz egyértelmű rangsort állítani a tényezők között, de úgy vélik, hogy a privát konstrukciók népszerübbek a gyenge és hiányos közoktatási rendszerekkel rendelkező országokban, ám hozzáteszik, hogy ezt valószínüleg jelentősen befolyásolhatja az egy före jutó jövedelemszint (Dang-Rogers 2008).

Érdemes megemlíteni, hogy az árnyékoktatásbeli részvétel és a magánközoktatás aránya között érzékelhető negatív korreláció állapítható $\operatorname{meg}^{8}$ (2. táblázat), amit interpretál-

2. táblázat: $A z$ árnyékoktatásbeli részvétel és a privát közoktatásban való részvétel közötti korrelációs kapcsolat

\begin{tabular}{|c|c|c|c|c|}
\hline & \multicolumn{2}{|c|}{$\begin{array}{l}\text { A privát oktatásban részt vevő tanulók aránya } \\
\qquad(2009)\end{array}$} & \multicolumn{2}{|c|}{$\begin{array}{l}\text { Részvétel az árnyék- } \\
\text { oktatásban (2009) }\end{array}$} \\
\hline & $\begin{array}{c}\text { Általános iskola felső } \\
\text { tagozaton (Lower secondary) }\end{array}$ & $\begin{array}{l}\text { Középiskolában } \\
\text { (Upper secondary) }\end{array}$ & Férfi & Nő \\
\hline Ausztria & 8,9 & 10,4 & 29,1 & 33,3 \\
\hline Belgium & 60,3 & 56,3 & 22,1 & 24,7 \\
\hline Csehország & 8,6 & 6,4 & 42,3 & 49,3 \\
\hline Dánia & 2,5 & 13,5 & 18,6 & 18,1 \\
\hline Egy. Kir. & 25,8 & 2,2 & 49,2 & 54,9 \\
\hline Franciaország & 21,8 & 31,0 & 39,1 & 45,4 \\
\hline Japán & 8,9 & 7,5 & 54,3 & 58,9 \\
\hline Kanada & 9,0 & 15,4 & 21,4 & 21,8 \\
\hline Korea & & 1,7 & 76,0 & 84,8 \\
\hline Magyarország & 18,4 & 45,7 & 38,0 & 41,6 \\
\hline Németország & 17,1 & 28,0 & 33,3 & 37,5 \\
\hline Norvégia & 3,1 & 9,5 & 24,8 & 24,7 \\
\hline Portugália & 12,4 & 20,0 & 47,5 & 53,2 \\
\hline Spanyolország & 6,4 & 12,3 & 53,1 & 57,6 \\
\hline Svájc & 32,2 & 22,5 & 25,8 & 26,9 \\
\hline Szlovákia & 8,0 & 6,7 & 43,4 & 44,3 \\
\hline Új-Zéland & 14,9 & 37,5 & 24,8 & 24,0 \\
\hline USA & 8,4 & 8,4 & 26,4 & 27,6 \\
\hline Korreláció - ffi & $-0,1749$ & $-0,4219$ & & \\
\hline Korreláció - nő & $-0,1286$ & $-0,3982$ & & \\
\hline
\end{tabular}

Forrás: A privát közoktatási arány forrása: UNESCOdatabase, az árnyékoktatási részvételé Kim 2013

8 A magánközoktatás és az árnyékoktatás lehetséges kapcsolatára Györgyi Zoltán hívta fel a figyelmemet, amit ezúton is köszönök. 
hatunk úgy, hogy annál magasabb az árnyékoktatásban való részvétel, minél alacsonyabb a magánközoktatásban tanulók aránya. Ha azt is feltételezzük - amit számos közgazdász megtesz (pl. Friedman) -, hogy a magánközoktatás jobb színvonalú, mint a közösségi, akkor ez az összefüggés azt látszik igazolni, hogy a gyengébb közoktatás előmozdítja az árnyékoktatásban való részvételt.

Zhang és Bray megközelítése szerint: „az árnyékoktatás fejlődését olyan makroszintű tényezők alakítják ki, mint a gazdasági növekedés, a kulturális hagyományok és a kormányzati politikák, valamint a mikrotársadalmi tényezők, ideértve a családi struktúrákat, a társadalmi-gazdasági különbségeket és az iskolai szintű politikákat" (Zhang-Bray 2016: 1).

A következőkben kicsit részletesebben rápillantunk a legfontosabb gazdasági és társadalmi motivációkra, amelyek az árnyékoktatás fejlődését befolyásolják.

A mainstream közgazdaságtan egyik alapteóriája az emberi tőke elmélet. Jóllehet Theodore Schultz az emberi tőkét növelő ráfordításokat - az egészségügy és a munkaerőpiac mozgásának költségei mellett - alapvetően a formális, a munkahelyi és a felnőtt oktatás kiadásaiban határozta meg (Schultz 1983: 60), azonban nyilvánvaló, hogy a formális képzést kiegészítő árnyékoktatás kiadásai is egyértelműen illeszkednek a gondolatmenetébe. A család befektetése az árnyékképzésbe tehát az emberi tőke természetes növekedése. Országos szinten az árnyékképzés pozitív szerepet játszik a nemzet humántőke-felhalmozódásában és a gazdasági növekedésben. Emberi tőke szempontjából az árnyékképzés egy másik lehetőség a családok számára, hogy befektessenek gyermekeik humán tőkéjének megszerzésébe a munkaerőpiaci sikeresség érdekében. Ennek oka az, hogy úgy gondolják, hogy az ilyen beruházásnak számos fontos hatása van gyermekeik munkalehetőségeire és jólétére. Ebből a szempontból a család befektetése az árnyékképzésbe tehát az emberi tőke természetes növekedése (Byung-Chung-Baker 2018, hivatkozva Heyneman 2011-re és Dang-Rogers 2008-ra).

Ugyanakkor hozzá kell tenni, hogy az emberi tőkeelmélet sok esetben nem feltétlenül magyarázza az egyéni oktatási kiadások növekedését. Ugyanis - mint jelen sorok írója több hazai adatokkal történt számítása során is találkozott azzal - nem egy olyan felsőfokú végzettség van (pl. szociális munkás, óvodapedagógus, tanító stb.), amely esetében jelen értéken számítva a ráfordítások (a tandíj, elmaradt kereset, megélhetési költség) meghaladják az életkereset növekedését, elsősorban a nők esetében. Ha ezeknél a végzettségeknél a felsőoktatásra való felkészülés vagy a felsőfokú képzés során igénybe vett árnyékoktatási szolgáltatások (pl. magánnyelvtanulás, nyelvvizsgára való felkészítés) költségeit is figyelembe vesszük, az oktatási befektetés meg nem térülése még jelentősebb lesz. Ezt a gyanút erősíti a 3. táblázat is, amely a felsőoktatás egyéni magánköltségeinek megtérülési rátája és az árnyékoktatás közötti kapcsolatot vizsgálja a mindkét tényezö szempontjából adatközlő OECD-országok halmazán. Viszonylag gyenge korreláció mellett, de úgy tűnik, hogy miközben a férfiak esetében a megtérülés és az árnyékoktatásbeli részvétel pozitív kapcsolatban áll, addig a nők esetében negatív a kapcsolat (bár tegyük hozzá, hogy rendkívül gyenge). Magyarul a nők esetében az árnyékoktatás befektetései feltételezhetően kevésbé térülnek meg. Mégis a nők részvétele magasabb! Ami arra utal, hogy messze nem csak gazdasági motívumok léteznek.

Ez mindamellett nem változtat azon a tényen, hogy országos szinten az árnyékképzés pozitív szerepet játszik a nemzet humántőke-felhalmozódásában és a gazdasági növe- 
3. táblázat: A felsőoktatás magánköltségeinek egyéni megtérülési rátája és az árnyékoktatásban való részvétel kapcsolata

\begin{tabular}{|c|c|c|c|c|}
\hline & \multicolumn{2}{|c|}{$\begin{array}{c}\text { Az oktatás egyéni megtérülési rátája } \\
\text { (2010-2016 átlag) (\%) }\end{array}$} & \multicolumn{2}{|c|}{$\begin{array}{l}\text { Részvétel az árnyékoktatásban } \\
(2009)(\%)\end{array}$} \\
\hline & $\begin{array}{c}\text { Felsőfokú } \\
\text { végzettségü férfi }\end{array}$ & $\begin{array}{c}\text { Felsőfokú } \\
\text { végzettségú nő }\end{array}$ & Férfi & Nő \\
\hline Ausztria & 11,1 & 9,7 & 29,1 & 33,3 \\
\hline Belgium & 10,7 & 15,8 & 22,1 & 24,7 \\
\hline Kanada & 14,7 & 17,0 & 21,4 & 21,8 \\
\hline Csehország & 15,8 & 12,6 & 42,3 & 49,3 \\
\hline Dánia & 10,7 & 16,2 & 18,6 & 18,1 \\
\hline Franciaország & 12,1 & 14,7 & 39,1 & 45,4 \\
\hline Németország & 12,8 & 11,3 & 33,3 & 37,5 \\
\hline Magyarország & 22,7 & 19,4 & 38,0 & 41,6 \\
\hline Írország & 26,1 & 39,0 & 26,1 & 29,1 \\
\hline Korea & 18,8 & 15,4 & 76,0 & 84,8 \\
\hline Új-Zéland & 10,0 & 13,2 & 24,8 & 24,0 \\
\hline Norvégia & 7,9 & 13,7 & 24,8 & 24,7 \\
\hline Portugália & 12,6 & 16,8 & 47,5 & 53,2 \\
\hline Szlovákia & 17,4 & 15,9 & 43,4 & 44,3 \\
\hline Spanyolország & 12,1 & 16,2 & 53,1 & 57,6 \\
\hline Svájc & 14,0 & 14,0 & 25,8 & 26,9 \\
\hline Egyesült Királyság & 10,5 & 12,8 & 49,2 & 54,9 \\
\hline USA & 16,0 & 16,3 & 26,4 & 27,6 \\
\hline Korreláció & 0,2071 & $-0,1173$ & & \\
\hline
\end{tabular}

Forrás: Az oktatás megtérülési rátáinak a forrása Education at a Glance 2019 és 2013, az árnyékoktatási részvételé Kim 2013

kedésben (Byung-Chung-Baker 2018, hivatkozva Dang-Rogers 2008-ra és Heyneman 2011-re).

Egy másik magyarázat az árnyékképzés igénybevételére a szociológiai megközelítés, amely - mint az oktatási rendszerbeli képzés is - a társadalmi státusz újratermelésére vagy növelésére szolgál, azaz társadalmi tőke termelését célozza. Ez annyiban különbözik az emberi tőkétől, amennyiben a közgazdaságtan különbözik a szociológiától. Farkas a következőképpen magyarázza a két tudományág tőkefelfogásának eltéréseit: „A szociológiában használt tőke vagy társadalmi tőke kifejezés fóleg a közgazdaságtan tőke kifejezéséből származik. A közgazdaságtanban azonban a tőke hagyományosan kialakult fogalmát kiterjesztették az úgynevezett emberi tőkére is. [...] A közgazdaságtanban elfogadott tágabb értelmezéséhez képest a szociológiai irodalomban még tágabban értelmezik a tőke fogalmát. [...] A tőkére vagy társadalmi tőkére vonatkozó szociológiai felfogások főleg Pierre Bourdieu és James S. Coleman felfogásához kapcsolódnak." (Farkas 
2013). Anheirer és szerzőtársai Bourdieu tőkefogalmáról azt írják, hogy az „tágabb, mint a tőke közgazdaságtanban használatos monetáris fogalma: a tőke nála általános »erőforrás«, mely éppúgy ölthet monetáris és nem monetáris, mint kézzelfogható és megfoghatatlan formát." (Anheirer-Gerbardos-Romo 2005: 79.)

Magyarul - a szociológiai tőkeképzés aspektusából vizsgálva - az elitcsaládok azért keresik az árnyékképzést, hogy gyermekeik számára megújítsák elit státuszukat. Ebből az elméleti aspektusból az árnyékoktatás a társadalmi egyenlőtlenség termelőjeként tekinthető. Az árnyéknevelést egyre inkább a felső középosztályú családok „összehangolt termesztés" stratégiájának részeként tekintik gyermekeik társadalmi mobilitásának fokozása érdekében (Byung-Chung-Baker 2018, hivatkozva Lareau 1989-re, Park et al. 2011-re).

Egy közgazdasági megközelítés is rámutat arra, hogy „az árnyékoktatás, a privát oktatási szolgáltatások vásárlása jelentősen növeli az oktatáshoz kapcsolódó háztartási költségeket. Ez viszont növeli annak valószínűségét, hogy az alacsony jövedelmü családok nem képesek fedezni az oktatással járó költségeket, súlyosbítva a meglévő társadalmi egyenlőtlenségeket." (RTE 2014: 29.)

A fenti megközelítések nem adnak magyarázatot az árnyékoktatás országok között tapasztalható mennyiségi és szerkezeti eltéréseire. Ezekre a nemzetközi különbségekre vonatkozóan is több megközelítés létezik.

$\mathrm{A} z$ egyik a kulturális úttól függő modell. Az árnyékoktatás különösen jelentős teret kapott Kelet-Ázsiában. A kutatók különböző tényezőkre mutattak rá az árnyékképzés ázsiai országokban tapasztalható dominanciájának magyarázataként: a konfucianizmustól, az oktatási rendszer tesztközpontúságán keresztül az oktatási képesítések és a munkalehetőségek közötti szoros kapcsolatokig (Byung-Chung-Baker 2018, hivatkozva Bray 1999-re, valamint Stevenson-Baker 1992-re). Az árnyékképzés globális növekedésével azonban ezek a kulturális magyarázatok elveszítik relevanciájukat. Ennek ellenére a kutatások arra utalnak, hogy az ázsiai társadalmakban az akadémiai eredmények és az árnyékképzés közötti kapcsolat valamivel eltérőbb mintázatú, mint máshol. Néhány ázsiai országban, mint például Korea és Thaiföld, a magas teljesítményt nyújtó hallgatók nagyobb valószínűséggel használják az árnyékképzést, mint sok más országban, míg más országokban ennek az ellenkezője igaz (Byung-Chung-Baker 2018, hivatkozva Baker et al. 2001-re). Vagy például egy kutatás megállapította, hogy az Egyesült Államokban élő ázsiai származású gyermekek nagyobb valószínűséggel használják a SAT előkészítő szolgáltatásokat - az árnyékképzés amerikai formáját -, mint bármely más etnikai csoport (Byung-Chung-Baker 2018, hivatkozik Byun-Park 2012-re). Úgy tűnik tehát, létezik valamilyen, az ázsiai társadalmakra jellemző kulturális és történelmi minta (Byung-Chung-Baker 2018).

A nemzetközi különbségeket magyarázó másik megközelítés szerint az országok közötti különbségek az árnyékoktatás használatában részint a magas téttel bíró tesztek nagyobb mértékủ használata, részint az oktatás alacsonyabb szintje miatt alakulnak ki (Byung-Chung-Baker 2018, hivatkozva Baker et al. 2001-re). A fejlödő társadalmakban a magas szintű tesztelés és az oktatási képesítések fontosabb szerepet játszanak az oktatási és munkaerőpiaci lehetőségek elérésében, mint a gazdaságilag fejlett társadalmakban. Ezenkívül a közoktatás minősége általában alacsony vagy szerény a gazdaságilag elmaradott társadalmakban, így a szülőknek és a tanulóknak jobb oktatást kell keresniük a magánszektorból, például a magániskolákban és a privát tutorálásban (Bray 1999). 
Ennek eredményeként a fejlődő társadalmakban a hallgatók inkább az árnyékképzésre támaszkodnak, mint a gazdaságilag fejlett társadalmakban (Byung-Chung-Baker 2018). Ugyanakkor miközben a kutatások úgy találták, hogy az alacsonyabb szintű oktatásfinanszírozással rendelkező társadalmakban az árnyékképzés szélesebb körü, arra nem találtak bizonyítékot, hogy a tesztelés magas aránya kapcsolódna az árnyékképzés globális növekedéséhez (Byung-Chung-Baker 2018, hivatkozva Baker et al. 2001-re).

Egy további megközelítés az árnyékoktatás nemzetközi különbségeinek magyarázatára a neoinstitucionalista elméletre támaszkodik. Lényege, hogy a kiterjedt árnyékképzés elsősorban az oktatás növekvő központi szerepével jár együtt, amelyet a tömeges oktatás magas szintű intézményesítése kísér. Az institucionalista modell pozitív kapcsolatot jósol az oktatás beiratkozási arányai és az árnyékképzés igénybevételének mértéke között, azaz az oktatás világszerte egyre növekvő jelentőségével a jobban iskolázott társadalmakban a hallgatók nagyobb valószínüséggel használják az árnyékképzést, mint a kevésbé iskolázott társadalmakban. A formális oktatás fokozott fontossága ugyanis egyidejűleg befolyásolta a nemzetállamokat és a családokat is. Az államok arra törekszenek, hogy minden gyermek számára egyenlőbb és magasabb színvonalú oktatást nyújtsanak. Elvileg az egyenlőbb és magasabb színvonalú oktatást nyújtó társadalom családjai várhatóan kevésbé motiváltak az oktatás megszerzésére a magánszektorból. Az intézményi modell azonban mást sugall. Ez a helyzet arra motivál sok családot, hogy különféle oktatási formákat vegyen igénybe, amelyek segítik gyermekeik teljesítményének javulását az iskolában (Baker-LeTendre 2005). Park (2013) például azt bizonyította, hogy Koreában tekintettel arra, hogy a középiskolai végzettséggel rendelkezők több mint 70\%-a folytatja tanulmányait egyetemen - sok koreai család, különösen a magas szocioökonómia státuszszal rendelkezők, továbbra is különféle árnyékképzési szolgáltatásokat keres gyermekeik számára annak ellenére, hogy a kormány erőfeszítéseket tett egy rendkívül méltányos állami iskolai rendszer kiépítésére. (Byung-Chung-Baker 2018.) Magyarul arról van szó, hogy az állam egységesítési törekvései éppen hogy olyan egyéni/családi aspirációkat ébresztenek, amely a magas társadalmi státuszú családokat az állami oktatási rendszerből való kiválás vagy az arra való ráképzés felé tereli, hogy gyermekeik magasabb jövőbeli társadalmi, gazdasági státuszát elősegítsék.

A gazdasági elemzés végén érdemes röviden kitérni arra, hogy az árnyékoktatási (private tutoring, illetve private supplementary tutoring) piac igen dinamikusan növekvő piaci szegmentum. Egy elemzés szerint a globális magántulajdon-oktató piac 279,3 milliárd dollárt ér el 2027-re és a 2020-2027 közötti időszakban 7\%-os összetett éves növekedési rátával (CAGR) ${ }^{9}$ növekszik (Report Buyer 2020). Egy másik elemzés szerint az ázsiai csendes-óceáni országokban van a világ legnagyobb és leggyorsabban növekvő piaca az egyéni magánoktatásnak. Ebben a régióban globális magántulajdonú oktatási piac összetett éves növekedési rátája várhatóan eléri a 10,2\%-os értéket (Global Industry Analysts, Inc. 2016). Ez egy viszonylag intenzív növekedést jelent, ha összehasonlítjuk más piacokkal. Például a globális ruházati piac (global apparel market) esetében 2-4\% volt $^{10}$ a CAGR 2015-2020 között, viszont az elektromos járművek globális piacán 2019-

9 CAGR = Compound annual growth rate, összetett éves növekedési ráta, amely egy befektetés megtérülési rátáját méri egy időszak alatt. A CAGR ún. „simított” megtérülési ráta, mert egy befektetés növekedését méri úgy, mintha évente állandó ütemű lenne.

10 https://www.statista.com/statistics/821513/global-apparel-market-growth-forecast/ [Letöltve: 2020. 07. 15.] 
2027 között Észak-Amerikának és Európának várhatóan 27,5\%, illetve 25,3\% CAGRértékei lesznek. ${ }^{11}$

\section{Befejezésül}

A magánoktatásnak fontos következményei vannak a közvetlen érintettekre és a szélesebb társadalomra is. Kompenzálhatja az oktatási rendszer hiányosságait, növelheti a humán tőke felhalmozását szolgáló tanulást, valamint foglalkoztatást és jövedelmet biztosíthat az oktatók számára. Ugyanakkor az árnyékoktatás torzíthatja a mainstream tanterveket, és fokozhatja a társadalmi egyenlőtlenségeket" - írja Zhang és Bray, s azt is hozzáteszik, hogy ahol az iskolarendszerbeli tanárok olyan tanulóknak nyújtanak magánoktatást, akiket tanítanak az iskolákban, akkor ez a gyakorlat korrupciós veszélyt is jelent (Zhang-Bray 2016: 1).

Vannak olyan alternatív megközelítések, amelyek kritikusan azt állítják, hogy az árnyékoktatás nagy része parazita, és pazarolja mind a pénzügyi, mind az emberi erőforrásokat, amelyeket jobban lehetne használni más célokra, például az oktatási rendszer javítására (Bray 2007: 64).

Az árnyékképzés jelentős társadalompolitikai dilemmát jelent, mivel a kormányok általában nem tartják kívánatosnak az oktatás privatizációját, illetve a magánképzések kiterjedését a társadalmi igazságosság szempontjából, mivel az az egyenlőtlenségek növekedésével jár; másrészt azonban a magánoktatás szervezése és annak igénybevétele az emberek tanulási jogaihoz is kapcsolódik (Kim-Jung 2019: 188). Az árnyékoktatás oktatáspolitikai megítélése tehát általában nem kedvező, mivel ez a tevékenység a nemzeti oktatáspolitika felügyelete alól „kilóg”, sőt annak kritikájaként fogható fel, mert puszta létével a hivatalos oktatás hiányosságaira utal.

Ugyanakkor az árnyékoktatás lényegében a piac reagálása a hivatalos oktatási rendszer olyan sajátosságaira, mint az egyéni igények és képességek különbségeinek kezelésére való képtelenség vagy azoknak szándékos egalitárius kezelése, illetve az oktatási rendszer alacsony színvonala. Az árnyékoktatás ezen individualizációs hatása egyben a különböző társadalmi hátterű tanulók - akik gazdasági lehetőségeik okán eltérő mennyiségü árnyékoktatás igénybevételére képesek és hajlandók - eltérő képességszintjének, tanulmányi teljesítményének forrása. Ezzel a társadalmi különbségek átszármaztatásának egyik eszköze, amelyre az állam, az oktatáspolitika valamilyen módon reagál.

Közismert, hogy a közgazdaságtan megosztott az állam szerepét illetően. Joseph E. Stiglitz A kormányzati szektor gazdaságtana címü, széles körben ismert munkájában így ír: „Manapság a közgazdászok között az a felfogás érvényesül, hogy korlátozott kormányzati beavatkozás révén enyhíteni (tehát nem megszüntetni) lehet a legsúlyosabb gondokat. [...] Mindmáig jelentős vita folyik arról, hogy a kormányzatnak mennyire szűken vagy tágan értelmezett módon kell fellépnie a gazdaságban. Néhány közgazdász, például John Kenneth Galbraith úgy véli, hogy a kormányzatnak tevékenyebb szerepet kell vállalnia, más közgazdászok, például a Nobel-díjas Milton Friedman vagy a szintén Nobel-díjas George Stigler meggyőződése szerint a kormányzatnak szükebb körben kell fellépnie. Az ilyen álláspontokat az határozza meg, hogy az illető mennyire tekinti súlyosnak a piackudarcokat és hogyan értékeli a kormányzat korrekciós lehetőségeit." (Stiglitz 2000: 31.)

11 https://www.alliedmarketresearch.com/electric-vehicle-market [Letöltve: 2020. 07. 15.] 
A közgazdasági nézetek az oktatást illetően ugyanilyen megosztottak az egyik póluson azokkal a nézetekkel, amelyeknek az a meggyőződésük, hogy a piaci integrációjú oktatás szolgálja a leghatékonyabb és legminőségibb fejlődést (pl. Friedman 1996; Friedman-Friedman 1998), a másik póluson pedig a piaci oktatást, annak súlyos problémái és következményei miatt elvető nézetekkel (pl. Hirschman 1995, 2000). És ez az árnyékoktatás közgazdasági megközelítésére is igaz. Egyik póluson az árnyékoktatás bumánerőforrás és képességfejlesztő hatását hangsúlyozzák, és az állami beavatkozások hatékonyságát illetöen meglebetösen szkeptikusak, a másik póluson viszont az állam szabályozó szerepében hisznek, és a társadalmi egyenlötlenségek növekedése nyomán nagyobb károkat látnak, mint amit a bumáneröforrás-fejlödés hasznai jelentenek.

A jobboldali oktatáspolitikák az árnyékoktatási részvételt általában természetes egyéni törekvésnek tekintik, a baloldali oktatáspolitikák számára pedig általában, mint az esélyegyenlőséget megvalósító közoktatás akadálya tételeződik.

$\mathrm{A} z$ állam, a politika sohasem tudja megakadályozni az árnyékoktatásnak a társadalmi egyenlőtlenséget növelő hatását, legfeljebb tompítani képes azt. Kérdés, hogy képes-e az árnyékoktatás humánerőforrás-fejlesztő hatásait kihasználni, illetve annak társadalmi, gazdasági fejlesztő impulzusait elősegíteni. És az igazi kérdés, hogy ez a két ellentétes következmény milyen egyenleget mutat.

\section{IRODALOM}

Adair, Ph. (2012) Non-observed Economy in the European Union Countries (EU-15). A Comparative Analysis of Estimates. In: M. Pickhardt (ed.) Tax Evasion and the Shadow Economy. Norhthampton, Edward Elgar Publishing.

Anheier, H. K., Gerhards, J. \& Romo, F. P. (2005) A tőke és a társadalmi struktúra formái a kulturális mezőkben. Bourdieu társadalmi topográfiájának vizsgálata. In: LENGYEL Gy. \& Szántó Z. (eds) A gazdasági élet szociológiája. Budapest, Aula Kiadó. Letölthető: https://www.tankonyvtar.hu/hu/tartalom/tamop425/0010_2A_02_Lengyel_GyorgySzanto_Zoltan_szerk_A_gazdasagi_elet_szociologiaja/adatok.html [Letöltve: 2019. 12.28.)

Aurini, J. \& Davies, S. (2004) The Transformation of Private Tutoring. Education in a Franchise Form. Canadian Journal of Sociology / Cahiers canadiens de sociologie, Vol. 29. No. 3. (Summer) pp. 419-438.

Baker, D. P. \& LeTendre, G. K. (2005) National Differences, Global Similarities: World Culture and the Future of Schooling. Stanford, Stanford University Press.

Bray, M. (1999) The Shadow Education System: Private Tutoring and Its Implications for Planners. Paris, UNESCO International Institute for Educational Planning.

Bray, M. (2007) The Shadow Education System: Private Tutoring and Its Implications for Planners. (Second edition.) UNESCO, Paris.

Bray, M. (2011) The Challenge of Shadow Education. Private Tutoring and Its Implications for Policy Makers in the European Union. Brussels, European Commission.

Buchmann, C., Condron, D. J. \& Roscigno, V. J. (2010) Shadow Education, American Style. Test Preparation, the SAT and College Enrolment. Social Forces, Vol. 89. No. 2. pp. 435-462. 
Byung, S-Y., Chung, H. J. \& Baker, D. (2018) Global Patterns of the Use of Shadow Education. Student, Family, and National Influences. Research in the Sociology of Education, Vol. 20. pp. 71-105.

Ceymun, E. \& ÖZtunali, O. (2012) Shadow Economies around the World. Model Based Estimates Working Papers 2012/05. Bogazici University, Department of Economics.

Ciutiene, R., Meiliene, E., Savaneviciene, S. \& Vaitievicius, S. (2015) Interdependence between Human Capital and the Powe of a Shadow Economy. Lithuanian Case Sstudy. Technological and Economic Development of Economy, Vol. 2. No. 3. pp. 460-482.

Dang, H-A. \& Rogers, H. (2008) The Growing Phenomenon of PrivateTutoring. Does It Deepen Human Capital, Widen Inequalities, or Waste Resources? World Bank. http:// documents.worldbank.org/curated/en/620421468169465126/pdf/767860JRN0WBRO 00Box374387B00PUBLIC0.pdf [Letöltve: 2019. 12. 28.)

Education at a Glance (2013) OECD Indicators. Paris, OECD.

Education at a Glance (2019) OECD Indicators. Paris, OECD.

Elgin, C. \& Oztunali, O. (2012) Shadow Economies around the World. Model Based Estimates. Working Paper 2012/05. Boğaziçi University, Department of Economics.

Farkas Z. (2013) A társadalmi tőke fogalma és típusai. Szellem és Tudomány, Vol. 4. No. 2. pp. 106-133.

Friedman, M. (1996) Kapitalizmus és szabadság. Budapest, Akadémiai Kiadó.

Friedman, M. \& Friedman, R. (1998) Választhatsz szabadon. Budapest, Akadémiai Kiadó.

Global Industry Analysts, Inc. (2016) The Global Market for Private Tutoring Services Is Forecast to Reach US\$227 Billion by 2022. https://strategyr.blogspot.com/2016/10/theglobal-market-for-private-tutoring.html [Letöltve: 2020. 07. 15.)

Hirschman, A. O. (1995) Kivonulás, tiltakozás, büség. Budapest, Osiris Kiadó.

Hirschman, A. O. (2000) Versengö nézetek a piaci társadalomról és egyéb újkeletü irások. Budapest, Jószöveg Mühely Kiadó.

KIm, H-K. (2013) An Analysis of the Causes of Shadow Education in the Era of the Schooled Society. Doctor of Philosophy Dissertation in Educational Theory and Policy. https:// etda.libraries.psu.edu/files/final_submissions/9089 [Letöltve: 2019.12.28.)

Kim, Y. CH. \& Jung, J-H. (2019) Shadow Education as Worldwide Curriculum Studies. Palgrave Macmillan.

Magyar Á. Zs. (2009) SAT. Érettségi-felvételi másképpen. Interjú Gordon Győri Jánossal. Anyanyelv-pedagógia, Vol. 1. http://www.anyanyelv-pedagogia.hu/cikkek.php?id=157 [Letöltve: 2020. 01. 04.)

Medina, L. \& Schneider, F. (2018) Shadow Economies around the World: What Did We Learn over the Last 20 Years? IMF Working Papers.

PARK, H. (2013) Re-evaluating Education in Japan and Korea. New York (NY), Routledge.

Report Buyer (2020) Global Private Tutoring Industry Market Report. https://www. reportbuyer.com/product/552740/global-private-tutoring-industry.html\#free-sample [Letöltve: 2020.07. 15.)

RTE (2014) Privatisation of Education. Global Trends of Human Rights Impacts. London, Right to Education Project, ActionAid International.

Schultz, Th. W. (1983) Beruházások az emberi tőkébe. Budapest, Közgazdasági és Jogi Kiadó.

Sıк E (1996) Egy ló-öszvér a lovakról és a szamarakról. Adalék a második gazdaság hazai eszmetörténetéhez. Közgazdasági Szemle, Vol. XLIII. (július-augusztus) pp. 704-725. 
Stiglitz, J. E. (2000) A kormányzati szektor gazdaságtana. Budapest, KJK-Kerszöv.

Zhang, W. \& Bray, M. (2016) Shadow Education. In: SH. Guo \& Y. Guo (eds) Spotlight on China. Changes in Education under China's Market Economy. Rotterdam, Sense Publishers. pp. 85-99.

A cikk a Creative Commons Attribution 4.0 International License (https://creativecommons.org/licenses/ by/4.0/) feltételei szerint publikált Open Access közlemény, melynek szellemében a cikk bármilyen médiumban szabadon felhasználható, megosztható és újraközölhető, feltéve, hogy az eredeti szerző és a közlés helye, illetve a CC License linkje és az esetlegesen végrehajtott módosítások feltüntetésre kerülnek. (SID_1) 